\title{
Kebijakan Kriminalisasi Dalam Peraturan Daerah Dan Sinkronisasi Dengan Hukum Pidana Kodifikasi
}

\author{
Teguh Prasetyo \\ Dosen Fakultas Hukum Universitas Slamet Riyadi Surakarta \\ prasetyo_teguh@yahoo.co.id
}

\begin{abstract}
The synchronization of criminal provisions in the residential decrees with the codified criminal law has not yet been made due to variety of the legal sources to which residential decrees may refer. Among the differences which need synchronization are the difference in the provisions of witnesses and also the differences in the interpretation made by the regulators.
\end{abstract}

Keywords: Policy, criminalization, Local Government Regulation, synchronization.

\section{Pendahuluan}

Kajian terhadap kebijakan kriminalisasi Peraturan Daerah untuk mewujudkan sinkronisasi hukum pidana lokal dengan hukum pidana kodifikasi dirasakan penting, paling tidak didasarkan pada beberapa alasan Pertama, munculnya persoalan di sekitar Perda "bermasalah" antara lain disebabkan adanya semangat berlebihan dari Pemerintah Daerah dalam meningkatkan pendapatan daerah, dengan berlomba untuk sebanyak-banyaknya membuat Peraturan Daerah. Agar Perda itu ditaati maka masing-masing daerah merumuskan kebijakan kriminalisasi dalam Perda, yang rumusannya berbeda-beda antara satu daerah dengan daerah lainya. Kedua, ada sebagian Perda yang dipandang bermasalah karena dalam menentukan kebijakan kriminalisasi bertentangan dengan aturan yang lebih tinggi, hal ini terjadi karena ketiadaan aturan operasional yang mengaturnya, sehingga setiap daerah menafsirkan sendiri kewenangan apa saja yang ada pada dirinya.

Pembagian kewenangan antara Pemerintah Pusat dengan Pemerintah Daerah pada pelaksanaan desentralisasi di Indonesia berdasarkan UU 
Nomor 22 Tahun 1999 Tentang Pemerintahan Daerah yang diperbaharui dengan UU Nomor 32 Tahun 2004 tentang Pemerintahan Daerah menganut pola General Competences atau otonomi luas, dengan pengecualian sebagaimana disebutkan dalam UU Nomor 32 Tahun 2004 Pasal 10 ayat (3), “Urusan pemerintahan ${ }^{1}$ yang menjadi urusan pemerintah meliputi: kewenangan bidang politik luar negeri, pertahanan, keamanan, yustisi, moneter dan fiskal nasional, dan agama".

Di dalam UU Nomor 32 Tahun 2004, khususnya pada Pasal 1 butir 5 ditegaskan bahwa otonomi daerah adalah hak, wewenang, dan kewajiban daerah otonom untuk mengatur dan mengurus sendiri urusan pemerintahan dan kepentingan masyarakat setempat sesuai dengan peraturan perundang-undangan.

Peraturan Daerah ${ }^{2}$ mengatur urusan rumah tangga di bidang otonomi dan urusan rumah tangga di bidang tugas pembantuan. Di bidang otonomi, Peraturan Daerah dapat mengatur segala urusan pemerintahan dan kepentingan masyarakat. ${ }^{3}$

Hukum Pidana dalam perkembangannya ternyata semakin banyak digunakan dan diandalkan dalam rangka mengatur dan menertibkan masyarakat melalui peraturan perundang-undangan. Dinamika hukum dapat terlihat dari adanya kebijakan penggunaan sanksi pidana melalui pencantuman bab tentang "ketentuan sanksi pidana" pada bagian akhir sebagian besar produk peraturan perundang-undangan di Indonesia. Pencantuman bab tentang ketentuan sanksi pidana tersebut tidak hanya terlihat dalam produk peraturan perundang-undangan pusat yang

${ }^{1}$ Dalam menyelenggarakan urusan pemerintah sebagaimana dimaksud pada Pasal 10 ayat (3) UU Nomor 32 Tahun 2004, Pemerintah menyelenggarakan sendiri atau dapat melimpahkan sebagain urusan pemerintah kepada perangkat Pemerintah atau wakil Pemerintah di daerah atau dapat menugaskan kepada pemerintah daerah dan/atau pemerintah desa. Lihat Pasal 10 ayat (4) UU Nomor 32 Tahun 2004 tentang Pemerintahan Daerah.

${ }^{2}$ Materi muatan Peraturan Daerah mengandung asas-asas: a. pengayoman; $b$. kemanusiaan; c. kebangsaan; d. kekeluargaan; e. kenusantaraan; f. bhineka tunggal ika; g. keadilan; h. kesamaan kedudukan dalam hukum dan pemerintahan; i. ketertiban dan kepastian hukum; j. keseimbangan, keserasian, dan keselarasan. Selain asas ini Peraturan daerah dapat memuat asas lain sesuai dengan substansi Peraturan daerah yang bersangkutan. Lihat Pasal 138 ayat (1) (2) Undang-undang Nomor 32 Tahun 2004 tentang Pemerintahan Daerah.

${ }^{3}$ Bagir Manan, Menyongsong Fajar Otomoni Daerah, PSH FH UII, Yogyakarta, 2002, hlm. 72. 
berbentuk "Undang-undang", melainkan dapat terlihat pula dalam produk peraturan perundang-undangan lokal yang berbentuk "Peraturan Daerah". 4

Pembentukan Peraturan Daerah oleh Pemerintah Daerah dapat dilakukan untuk kebijakan kriminalisasi ${ }^{5}$ dalam Peraturan Daerah dan untuk penegakannya dapat membentuk pejabat-pejabat yang diberi wewenang untuk melakukan penyidikan terhadap dugaan pelanggaran atas Peraturan Daerah.

Sebagai pedoman dalam pembuatan Peraturan Daerah yang memuat ketentuan pidana tertuang di dalam Pasal 71 ayat (2) UU Nomor 22 Tahun 1999, hal itu dinyatakan sebagai berikut. "Peraturan Daerah dapat memuat ancaman pidana kurungan paling lama enam bulan atau denda sebanyakbanyaknya Rp 5.000.000,00 (lima juta rupiah) dengan atau tidak merampas barang tertentu untuk daerah, kecuali jika ditentukan lain dalam peraturan perundang-undangan". Kemudian menurut UU Nomor 32 Tahun 2004 diatur dalam Pasal 143 ayat (2), yang berbunyi: "Peraturan Daerah dapat memuat ancaman pidana kurungan paling lama enam bulan atau denda paling banyak Rp 50.000.000,00 (lima puluh juta rupiah)".

${ }^{4}$ Produk peraturan perundang-undangan yang di dalamnya mencantumkan bab tentang "ketentuan pidana" yaitu dapat dijumpai pada Undang-Undang Nomor 12 Tahun 1985 tentang Pajak Bumi dan Bangunan, Undang-Undang Nomor 23 Tahun 1992 tentang Kesehatan, Undang-Undang Nomor 8 Tahun 1995 tentang Pasar Modal, Undang-Undang Nomor 23 Tahun 1997 tentang Pengelolaan Lingkungan Hidup, Undang-Undang Nomor 8 Tahun 1999 tentang Perlindungan Konsumen dan masih banyak lagi produk peraturan perundang-undangan yang lain.

${ }^{5}$ Menurut Barda Nawawi Arief proses kriminalisasi harus memperhatikan berbagai aspek pertimbangan sebagai berikut:a) Penggunaan hukum pidana harus memperhatikan tujuan pembangunan nasional, yaitu mewujudkan masyarakat adil dan makmur yang merata material spiritual berdasarkan Pancasila; b) Perbuatan yang diusahakan untuk dicegah atau ditanggulangi dengan hukum pidana harus merupakan perbuatan yang tidak dikehendaki, yaitu perbuatan yang mendatangkan kerugian (material dan atau spritual) atas warga masyarakat; c) Penggunaan hukum pidana harus pula memperhitungkan prinsip biaya dan hasil (cost and benafit principles) juga sosial cost atau biaya sosial; d) Penggunaan hukum pidana harus pula memperhatikan kapasitas atau kemampuan daya kerja dari badan-badan penegak hukum, yaitu jangan sampai ada kelampauan beban tugas (overbelasting). Lihat Barda Nawawi Arif, Bunga Rampai Kebijakan Hukum Pidana, PT. Citra Aditya Bakti, Bandung, 1996, hlm. 33-34. 
Kebijakan kriminalisasi dalam Peraturan Daerah yang tidak sinkron di Indonesia, dapat di kelompakan menjadi empat macam, yaitu: ${ }^{6}$

1. Kebijakan kriminalisasi dari delegasi Undang-undang, contohnya Peraturan Daerah tentang Retribusi dan Pajak;

2. Kebijakan kriminalisasi yang sudah diatur dalam hukum pidana kodifikasi, contohnya Peraturan Daerah tentang miras, pelacuran;

3. Kebijakaran kriminalisasi dari hukum Islam, contohnya Qanun Provinsi Nangroe Aceh Darussalam Nomor 11 Tahun 2002 tentang Pelaksanaan Syariat Islam Bidang Aqidah, Ibadah dan Syari'at Islam;

4. Kebijakan kriminalisasi dari hukum adat, contohnya Peraturan Daerah mengenai tradisi adat yang masih dipertahankan di daerah itu. Contohnya Peraturan Daerah Nomor 12 tahun 1999 tentang Penggalian Jalan, Mengubah Trotoar dan Pemancangan di Wilayah Kabupaten Daerah Tingkat II Badung.

Perbedaan kebijakan formulasi sanksi pidana masing-masing daerah dalam menentukan jenis atau maksimumnya sanksi pidana dalam Peraturan Daerah karena tidak ada pedoman yang pasti dan perbedaan antara satu undang-undang dengan undang-undang lain, sebagai contoh pada Pasal 143 ayat (2) UU Nomor 32 Tahun 2004. Apabila dihubungkan dengan UU Nomor 18 Tahun 1997 tentang Pajak dan Retribusi Daerah, ternyata tidak adanya kesetaraan. Jenis pidana maupun maksimum sanksi yang ditetapkan Pasal 37 sampai dengan Pasal 41 UU Nomor 18 Tahun 1997 tentang Pajak dan Retribusi Daerah yang menunjukkan bahwa maksimum sanksi pidana berkisar antara 6 bulan sampai dengan 2 tahun, sehingga ancaman pidana yang dijatuhkan dalam hal sanksi pidana pajak dan sanksi retribusi daerah dapat berupa jenis pidana kurungan atau pidana penjara. Keadaan ini tentu saja dapat menimbulkan persoalan utama ketika Pemerintah Daerah memformulasikan perbuatan yang dikenai sanksi pidana ke dalam Peraturan daerah khususnya mengenai pajak dan retribusi daerah.

Apabila merujuk pada UU Nomor 22 Tahun 1999 tentang Pemerintah Daerah, menurut ketentuan Pasal 71 ayat (2) Peraturan Daerah hanya dimungkinkan memuat ancaman sanksi pidana kurungan paling lama 6 (enam) bulan atau denda sebanyak-banyaknya Rp 5.000.000,00 (lima juta

${ }^{6}$ Lihat dalam Teguh Prasetyo, Kebijakan Kriminalisasi Peraturan Daerah Guna Mewujudkan Sinkronisasi Hukum Pidana Lokal dengan Hukum Pidana Kodifikasi, Disertasi, Program Pascasarjana Fakultas Hukum Universitas Islam Indonesia, Yogyakarta, 2006. 
rupiah), yang berbeda dengan Undang-undang Nomor 32 Tahun 2004 tentang Pemerintahan Daerah, Pasal 143 ayat (2) yang memungkinkan ancaman pidana kurungan paling lama 6 (enam) bulan atau denda paling banyak Rp 50.000.000,00 (lima puluh juta rupiah), tetapi apabila merujuk pada UU Nomor 18 Tahun 1997 tentang Pajak dan Retribusi Daerah ancaman pidana pada Peraturan Daerah dapat melampaui 6 bulan, dan pidananya dapat berupa pidana penjara. Adapun menurut ketentuan KUHP pidana perampasan kemerdekaan berupa jenis pidana kurungan maksimal hanya 1 (satu) tahun, maksimum ancaman pidana yang melebihi satu tahun berupa pidana penjara.

Kondisi faktual dengan adanya Peraturan Daerah yang bermasalah karena belum memperhatikan teori kebijakan kriminalisasi dalam perumusan Peraturan Daerah. Peraturan Daerah yang dibatalkan bertentangan dengan peraturan perundang-undangan di atasnya, kepentingan umum, juga tidak menggunakan standar hukum. Peraturan Daerah harus diukur dengan standar hukum nasional maupun internasional. Standar internasional seperti petty crime atau kejahatan ringan, di banyak negara petty crime tidak dijatuhi sanksi pidana hanya diproses di pengadilan dan ditunjukan kesalahannya, apabila dijatuhi pidana pelaksanaan pidananya bisa ditangguhkan (suspended sentence), bahkan bisa diberi maaf atau pardonable setelah dimaafkan ia bebas, akan tetapi apabila mereka melakukan lagi maka sanksi hukuman yang sekarang dan yang terdahulu digabung. Standar nasional Peraturan Daerah termasuk kejahatan ringan jenis pelanggaran, perkara cepat dengan sanksi pidana penjara tidak boleh lebih 1 (satu) tahun dan pidana kurungan atau alternatif benda dan dalam hal tertentu pidana bersyarat.

Dari uraian di atas dapat dirumuskan permasalahan yang menjadi kajian dalam tulisan ini, (1) apakah aspek kebijakan kriminalisasi dalam Peraturan Daerah telah sinkron dengan hukum pidana kodifikasi? (2) strategi apa yang perlu dikembangkan untuk mewujudkan sinkronisasi hukum pidana lokal dengan hukum pidana kodifikasi?

\section{Kebijakan Kriminalisasi Dalam Peraturan Daerah}

Kebijakan penggunaan sanksi pidana dalam Peraturan Daerah pada hakikatnya dapat dikatakan pula sebagai bagian "politik kriminal" atau "criminal policy". Menurut Marc Ancel, "criminal policy" dapat diberikan pengertian sebagai the rational organization of the control of crime by society. 
Dalam hubungan dengan masalah kriminalisasi, Muladi mengingatkan mengenai beberapa ukuran yang secara doktrinal harus diperhatikan sebagai pedoman, yaitu sebagai berikut. ${ }^{7}$

1. Kriminalisasi tidak boleh terkesan menimbulkan "overkriminalisasi" yang masuk kategori the misuse of criminal sanction.

2. Kriminalisasi tidak boleh bersifat ad hoc.

3. Kriminalisasi harus mengandung unsur korban (victimizing) baik aktual maupun potensial.

4. Kriminalisasi harus memperhitungkan analisa biaya dan hasil dan prinsip ultimum remedium.

5. Kriminalisasi harus menghasilkan peraturan yang enforceable.

6. Kriminalisasi harus mampu memperoleh dukungan publik.

7. Kriminalisasi harus mengandung unsur "subsosialitet" (mengakibatkan bahaya bagi masyarakat, sekalipun kecil sekali).

8. Kriminalisasi harus memperhatikan peringatan bahwa setiap peraturan pidana membatasi kebebasan rakyat dan memberikan kemungkinan kepada aparat penegak hukum untuk mengekang kebebasan itu.

Mengingat pentingnya tahap formulasi dalam fungsionalisasi atau operasionalisasi kebijakan hukum pidana (penal policy), maka kebijakan penggunaan sanksi pidana dalam Peraturan Daerah sebagai bagian dari kebijakan hukum pidana (penal policy) sudah seharusnya memperhatikan ukuran atau kriteria tersebut di atas. Dasar pertimbangan adanya kebijakan penggunaan sanksi pidana dalam Peraturan Daerah melalui pencantuman ketentuan (ancaman) pidana seharusnya tidak boleh melepaskan dari ukuran atau kriteria dalam kebijakan kriminalisasi.

Pembentuk peraturan tidak hanya menetapkan tentang perbuatanperbuatan yang dapat dikenai hukum pidana, tetapi juga menunjuk macammacam sanksi yang dapat diterapkan, begitu pula maksimum ukuran pidana. ${ }^{8}$

Penentuan sanksi apa yang sebaiknya digunakan atau dikenakan kepada si pelanggar mempunyai hubungan yang erat dengan sistem pidana dan pemidanaan. Sistem pidana dan pemidanaan tersebut dapat mencakup ruang lingkup yang cukup luas.

Kebijakan kriminalisasi Peraturan Daerah merupakan kompetensi/ kewenangan Pemerintah Daerah untuk membuat Peraturan Daerah, untuk mengetahui kompetensi ini, maka penulis menggunakan teori

${ }^{7}$ Muladi, Kapita Selekta Hukum Pidana, Badan Penerbit Universitas Diponegoro, Semarang, 1995, hlm. 256.

${ }^{8}$ Roeslan Saleh, Segi Lain Hukum Pidana, Ghalia Indonesia, Jakarta, 1984, hlm. 18. 
kompetensi/kewenangan. Prajudi Atmosudirjo ${ }^{9}$ membedakan antara wewenang (competence, bevoegdheid) atau kewenangan (authority, gezag). Dimaksud "kewenangan" adalah apa yang disebut "kekuasaan formal", kekuasaan yang berasal dari kekuasaan legislatif (diberikan oleh undangundang) atau dari kekuasaan eksekutif/administratif. Selanjutnya dikatakan, kewenagan yang biasanya terdiri atas beberapa wewenang adalah kekuasaan terhadap sesuatu bidang pemerintahan atau bidang urusan tertentu yang bulat. Sedangkan wewenang hanya mengenai sesuatu hal tertentu saja. Di dalam kewenangan terdapat wewenangwewenang (rechtsbevoegdheden). Wewenang adalah kekuasaan untuk melakukan sesuatu tindakan hukum publik, misalnya wewenang menandatangani atau menerbitkan surat-surat izin drai seorang pejabat atas nama menteri. ${ }^{10}$

Peraturan Daerah merupakan bagian dari tata urutan perundangundangan, jadi dalam merumuskan suatu Peraturan Daerah yang memiliki sinkronisasi dengan perundang-undangan nasional haruslah menggunakan teori perundang-undangan.

Dalam teori perundang-undangan juga harus tunduk pada asas-asas tertentu, yaitu: ${ }^{11}$

1. Asas yang bersumber pada politik konstitusi dan ketentuan UUD (asas konstitusional dalam penerapan hukum);

2. Asas tidak berlaku surut (nonretroaktif);

3. Asas peralihan hukum;

4. Asas pertingkatan peraturan perundang-undangan (lex superior derogat legi inferiori);

5. Asas aturan hukum yang khusus akan mengesampingkan aturan hukum yang umum (lex specialis derogat legi generali);;

6. Asas aturan hukum yang baru mengesampingkan atau meniadakan aturan hukum yang lama (lex posterior derogat legi priori);

7. Asas mengutamakan atau mendahulukan hukum tertulis dari hukum tidak tertulis;

8. Asas kepatuhan, keadilan, kepentingan umum, dan ketertiban umum.

${ }^{9}$ Prayudi Atmosudirdjo, Hukum Administrasi Negara, Ghalia Indonesia, Jakarta, 1981, hlm. 76.

${ }^{10} \mathrm{Ibid}$.

${ }^{11}$ Bagir Manan, Hukum Positif Indonesia: Satu Kajian Teoritik, FH UII Press, Yogyakarta, 2004, hlm. 52-65. 


\section{Konsep Dasar Kebijakan Kriminalisasi dalam Peraturan Daerah}

Menurut Barda Nawawi Arief ${ }^{12}$ dua pokok pikiran dalam kebijakan kriminal dengan menggunakan saran hukum pidana adalah masalah penentuan perbuatan apa yang seharusnya dijadikan tindak pidana dan sanksi apa yang sebaiknya dikenakan kepada pelanggar. Mendasarkan teori di atas dapat diketahui indikator-indikator konsep dasar kebijakan kriminalisasi dalam Peraturan Daerah. Indikatornya adalah :

(1) Alasan kebijakan kriminalisasi, baik alasan Peraturan Daerah yang tidak dilegasi undang-undang terhadap Peraturan Daerah tentang Pajak atau Retribusi Daerah;

(2) Jenis kriminalisasi dan jumlah Peraturan Daerah yang telah diundangkan oleh Pemeintah Daerah dari tahun 1999 sampai 2004;

(3) Sanksi pidana yang dirumuskan dalam Peraturan Daerah di Jawa Tengah baik sanksi pidana Peraturan Daerah yang tidak dilegalisasi undang-undang maupun sanksi pidana pada delegasi undang-undang yang terdiri dari Peraturan Daerah Pajak dan Peraturan Daerah Izin dan Retribusi;

(4) Perbuatan yang dilarang di dalam Peraturan Daerah, baik yang tidak delegasi undang-undang, maupun yang delegasi undang-undang;

(5) Peraturan Daerah yang mempunyai karakteristik daerah dan alasan pembuatan Peraturan Daerah disesuaikan dengan keadaan di daerah tempat Peraturan Daerah masing-masing diundangkan.

Pada prinsipnya tentang alasan pengundangan Peraturan Daerah yang tidak ada delegasi Undang-Undang yang bersumber dari larangan norma agama, dan norma sosial dan berbagai faktor yang mempengaruhi lingkungan:

(a) Jenis Peraturan Daerah minuman keras karena alasan bertentangan dengan norma agama dan norma sosial, serta berbahaya untuk kesehatan jasmani-rohani;

(b) Jenis Peraturan Daerah tuna susila karena alasan-alasan berdampak negatif bagi kehidupan masyarakat;

(c) Pengaturan pedagang kaki lima, karena alasan perlu menciptakan suasana tertib indah dan bersih di lingkungan kota;

(d) Usaha pertambangan umum, karena alasan sumber daya alam yang tidak dapat diperbaharui untuk itu harus dikelola oleh Pemerintah Daerah;

${ }^{12}$ Barda Nawawi Arief, Op., Cit 
(e) Perjudian karena alasan gangguan ketertiban, keamanan serta dampak sosial yang negatif.

Sedangkan pada alasan Peraturan Daerah delegasi undang-undang di Provinsi Jawa Tengah, pengundangan Peraturan Daerah yang bersumber untuk kepentingan Pajak Daerah dan pendapatan usaha potensi daerah secara ekonomis, dengan klaifikasi: (a) hotel, hiburan, reusturan, penerangan jalan, parkir, karena alasan untuk pajak dan retrebusi daerah; (b) usaha sarang burung untuk Pendapatan Asli Daerah (PAD). ${ }^{13}$

Demikian pula terhadap alasan Peraturan Daerah untuk ijin dan retribusi dengan delegasi undang-undang mencakup 6 (enam) obyek; pengujian kendaraan bermotor, rekreasi dan olah raga, pelayanan kesehatan, retribusi teminal, ijin trayek, usaha jasa konstruksi. Ke enam Peraturan Daerah tersebut diatas menitik beratkan untuk alasan merubah Pendapatan Asli Daerah (PAD), dan hanya untuk sebagian kecil untuk alasan penegakan hukum dan ketertiban masyarakat sebagai pelengkap norma hukum lokal yang akan dikembangkan pada Peraturan Daerah selanjutnya.

Berbagai aspek pertimbangan dalam menentukan kriminalisasi sebagaimana telah dikemukakan Barda Nawawi Arief tidak sepenuhnya dilakukan, penggunaan hukum pidana harus memperhatikan tujuan pembangunan nasional, perbuatan yang diusahakan untuk dicegah atau ditanggulangi dengan hukum pidana harus merupakan perbuatan yang tidak dikehendaki, yaitu perbuatan yang mendatangkan kerugian, penggunaan hukum pidana harus pula memperhitungkan prinsip biaya dan hasil, penggunaan hukum pidana harus pula memperhatikan kemampuan penegak hukum. Penulis mengusulkan dalam pembuatan kriminalisasi di samping memperhatian empat pertimbangan di atas, perlu ditambah dengan pertimbangan karakteristik daerah.

Alasan kriminalisasi Peraturan Daerah yang bukan merupakan delegasi undang-undang dilihat dari teori alasan kriminalisasi sudah mempertimbangkan alasan suatu perbuatan dilarang, yaitu tujuan pembangunan nasional, merupakan perbuatan yang tidak dikehendaki dan memperhitungkan prinsip biaya dan hasil, namun dalam perumusan Peraturan Daerah tidak menjelaskan tentang penegakan hukumnya, dalam penegakan hukum harus pula diperhatikan kapasitas atau kemampuan daya kerja dari badan-badan penegakan hukum. Alasan kriminalisasi Peraturan Daerah yang merupakan delegasi undang-undang

\footnotetext{
${ }^{13}$ Lihat dalam Teguh Prasetyo, Kebijakan Kriminalisasi... Op., Cit., hlm. 171-174
} 
karena adanya perubahan undang-undang, jadi Peraturan Daerah belum memperhatikan alasan kriminalisasi sesuai dengan teori kriminalisasi.

Konsep dasar dari pemerintah daerah dalam merumuskan sanksi pidana di dalam Peraturan Daerah yang tidak dilegasi undang-undang ternyata tidak ada keseragaman, sebagian Peraturan Daerah merumuskan sanksi dengan mencantumkan jumlah pidana minimal dan maksimal, sedangkan sebagain Peraturan Daerah hanya mencantumkan batas maksimal sanksi pidana yang dikenakan, dan jumlah denda yang dikenakan.

Perumusan Peraturan Daerah Provinsi/Kabupaten/Kota di Jawa Tengah belum ada keseragaman ukuran sanksi pidana dan Pemerintahan Daerah belum memahami bagaimana merumuskan penentuan sanksi yang baik, sehingga terjadi banyak perbedaan antara satu Peraturan daerah dengan Peraturan Daerah daerah lain yang mengatur hal yang sama, dengan akibat terjadi kebingungan masyarakat dalam mentaati aturan yang ada dalam Peraturan Daerah. ${ }^{14}$

Sanksi pidana dalam Peraturan Daerah masih menekankan pada sanksi pidana pembalasan (teori retributif), yang memandang bahwa pemidanaan merupakan pembalasan atas kesalahan yang telah dilakukan bertujuan memberikan penderitaan kepada pelanggar supaya ia merasakan akibat perbuatannya, dilihat dari jenis sanksi Peraturan Daerah yang ada di Jawa Tengah.

Pedoman umum sanksi dalam hukum pidana dapat dibagi menjadi sanksi pidana dan sanksi tindakan. Keduanya bersumber dari ide dasar yang berbeda. Sanksi pidana bersumber pada ide dasar: "mengapa diadakan pemidanaan", sedangkan sanksi tindakan bertolak dari ide dasar: "untuk apa diadakan pemidanaan itu".

Berdasarkan tujuannya, sanksi pidana dan sanksi tindakan juga bertolak dari ide dasar yang berbeda. Sanksi pidana bertujuan memberi penderitaan istimewa kepada pelanggar supaya merasakan akibat perbuatannya, sedangkan sanksi tindakan tujuannya lebih bersifat mendidik.

Sesuai dengan perkembangan ilmu pengetahuan hendaknya lebih menitikberatkan pada sanksi tindakan, sanksi itu merupakan sanksi yang tidak membalas, semata-mata ditujukan pada prevensi khusus, terhadap perlindungan masyarakat dari ancaman yang dapat merugikan kepentingan masyarakat itu.

${ }^{14}$ Ibid 
Penetapan sanksi dalam Peraturan Daerah, apapun jenis dan bentuk sanksi harus didasarkan pada kewenangan yang diberikan pada daerah dalam merumuskan Peraturan Daerah pidana dan diorientasikan pada standar tujuan pemidanaan. Setelah tujuan pemidanaan ditetapkan, barulah jenis dan bentuk sanksi apa yang paling tepat bagi pelanggaran Peraturan Daerah itu.

\section{Sinkronisasi Antar Hukum Pidana Lokal dengan Hukum Kodifikasi}

Hasil penelitian penulis menunjukkan bahwa di antara Peraturan Daerah yang dimintakan pengesahan oleh Menteri Dalam Negeri terdapat sembilan Peraturan Daerah yang dibatalkan. ${ }^{15}$ Demikian juga mengenai Peraturan Perundang-Undangan yang dijadikan dasar hukum bagi pembuatan Peraturan Daerah masih belum ada keseragaman, sehingga Pemerintah Daerah dalam membuat Peraturan Daerah merujuk pada peraturan perundang-undangan yang berbeda-beda. Pencantum

Tabel 1

Asas Sanksi Pidana dalam Hukum Pidana Kodifikasi

\begin{tabular}{|c|c|c|c|}
\hline No & Pengaturan & Tentang & Rumusan \\
\hline 1 & $\begin{array}{l}\text { Pasal } 1 \text { (ayat } 1 \text { ) } \\
\text { KUHP }\end{array}$ & Asas Legalitas & $\begin{array}{l}\text { Suatu perbuatan dapat dipidana } \\
\text { kecuali atas kekuatan aturan pidana } \\
\text { dalam perundang-undangan yang } \\
\text { telah ada sebelum perbuatan dilakukan }\end{array}$ \\
\hline 2 & Pasal 10 KUHP & Pidana & $\begin{array}{l}\text { Pidana terdiri atas: } \\
\text { a. Pidana Pokok: } \\
\text { 1. pidana mati } \\
\text { 2. pidana penjara } \\
\text { 3. pidana kurungan } \\
\text { 4. pidana denda } \\
\text { b. Pidana Tambahan : } \\
\text { 1. pencabutan hak-hak tertentu } \\
\text { 2. perampasan barang-barang } \\
\text { 3. pertentu } \\
\text { 3. pengumuman putusan hakim }\end{array}$ \\
\hline 3 & $\begin{array}{l}\text { Pasal } 12 \\
\text { ayat(1) KUHP } \\
\text { ayat (2) KUHP }\end{array}$ & Pidana Penjara & $\begin{array}{l}\text { Pidana penjara adalah seumur hidup } \\
\text { atau selama waktu tertentu.Pidana } \\
\text { penjara selama waktu tertentu paling } \\
\text { pendek adalah } 1 \text { hari dan paling lama } \\
\text { lima belas tahun berturut-turut. }\end{array}$ \\
\hline
\end{tabular}

${ }^{15} \mathrm{Ibid}, \mathrm{hlm} .217$ 


\begin{tabular}{|c|l|c|l|}
\hline 4 & $\begin{array}{l}\text { Pasal 18 ayat (1) } \\
\text { KUHP }\end{array}$ & Kurungan & $\begin{array}{l}\text { Kurungan paling sedikit adalah satu } \\
\text { hari dan paling lama satu tahun }\end{array}$ \\
\hline 5 & $\begin{array}{l}\text { Pasal } 30 \\
\text { ayat (1) KUHP } \\
\text { ayat (2) KUHP } \\
\text { ayat (3) KUHP }\end{array}$ & Denda & $\begin{array}{l}\text { Denda paling sedikit adalah dua puluh } \\
\text { lima senJika tidak dibayar, lalu diganti } \\
\text { dengan kurunganLamanya kurungan } \\
\text { pengganti paling sedikit adalah satu } \\
\text { hari dan paling lama enam bulan }\end{array}$ \\
\hline
\end{tabular}

ancaman pidana yang bebeda-beda diantara Peraturan Daerah yang ada karena peraturan perundang-undangan yang dijadikan acuan pemberian sanksi pidana juga berbeda-beda.

Tabel 1 menunjukkan bahwa asas legalitas dicantumkan memakai Pasal 1 ayat (1) KUHP, asas ini merupakan salah satu asas yang paling fundamental dalam hukum pidana. Berdasarkan asas legalitas seseorang tidak dapat dijatuhi pidana kecuali atas kekuatan aturan pidana dalam perundang-undangan yang telah ada, sebelum perbuatan dilakukan. Konsekuensi dari asas legalitas peraturan hukum pidana tidak boleh berlaku surut, tidak boleh analogi, dan harus tertulis.

Pidana diatur dalam ketentuan Pasal 10 KUHP yang menurut ketentuan pasal tersebut pidana dibagi menjadi dua yaitu pertama pidana pokok yang terdiri dari pidana mati, pidana penjara, kurungan, dan denda. Kedua pidana tambahan terdiri dari pencabutan hak-hak tertentu perampasan, perampasan barang-barang tertentu pengumuman putusan hakim.

Ketentuan Pasal 12 ayat (1) dan ayat (2) KUHP mengatur pidana penjara. Pidana penjara adalah seumur hidup atau selama waktu tertentu. Pidana penjara selama waktu tertentu adalah satu hari dan apaling lama lima belas tahun berturut-turut. Pasal 18 ayat (1) KUHP mengatur tentang kurungan, kurungan paling sedikit satu hari palaing lama satu tahun. Dalam Pasal 30 KUHP ayat (1), (2), (3) diatur tentang denda. Denda paling sedikit dua puluh lima sen jika tidak dibayar lalu diganti dengan kurungan. Lamanya kurungan pengganti paling sedikit satu hari dan paling lama enam bulan.

\section{Strategi yang Perlu Dikembangkan untuk Mewujudkan Sinkronisasi antara Hukum Pidana Lokal dengan Hukum Pidana Kodifikasi}

Peraturan Daerah yang ideal materi muatannya baik perumusan tindak pidana maupun sanksinya merupakan penjabaran peraturan perundang-undangan yang lebih tinggi, memuat kondisi daerah yang 
bersangkutan, tidak bertentangan dengan kepentingan umum dan peraturan perundang-undangan di atasnya.

Hasil penelitian menunjukkan banyak Peraturan Daerah yang dibatalkan karena perumusan tindak pidananya tidak memenuhi standar hukum, demikian juga tentang sanksi yang dirumuskan. Apabila proses pembuatan Peraturan Daerah sesuai dengan standar hukum yang ideal, Peraturan Daerah dapat berlaku efektif, karena telah memenuhi unsur yuridis, sosiologis dan fisiolofis. Kenyataan berlakunya Peraturan Daerah tidak sepenuhnya sesuai dengan yang diidealkan, banyak produk hukum dalam hal ini Peraturan Daerah tidak memenuhi semua elemen berlakunya hukum secara efektif.

Strategi yang perlu dikembangkan meliputi tiga bagian, aspek meteri hukum, aspek sanksi, dan aspek penegakan hukum. Sebagian Peraturan Daerah di Jawa Tengah tidak mencantumkan kualifikasi suatu perbuatan masuk pelanggaran atau kejahatan. Pembagian dua jenis tindak pidana ini sangat penting karena menjadi dasar konvensional. Seluruh sistem pidana di Indonesia, sekalipun akan ditinggalkan dalam penyusunan pembaharuan KUHP dan merupakan pemilihan yang juga penting dari sudut pandang hukum acara pidana, berkaitan dengan kompetensi absolut.

Merumuskan Peraturan Daerah pidana sedapat-dapatnya sinkron dengan hukum yang berada di atasnya dengan menggunakan prinsip "lex superiore derogat legi inferiore", juga harus diperhatikan aspek kesetaraan dan penyimpangan hukum dengan menggunakan prinsip "lex specialis derogat legi generalis", seperti Peraturan Daerah Nanggo Aceh Darusalam (NAD).

Pembagian sanksi pidana dalam Peraturan Daerah dapat dikualifikasikan sebagai menjadi sanksi kurungan, sanksi denda dan sanksi tindakan yang di sarankan dengan sanksi administrasi pada sanksi pidana dalam Peraturan Daerah pada umumnya menggunakan sanksi kurungan dan denda, walaupun ada beberapa Peraturan Daerah yang mencantumka sanksi administratif.

Pemerintahan Daerah dalam merumuskan sanksi pidana Peraturan Daerah harus memperhatikan batasan wewenang yang telah diberikan oleh peraturan di atasnya, dalam perumusan sanksi pidana tidak boleh bertentangan dengan wewenang yang telah di berikan, baik oleh undangundang atau hukum pidana kodifikasi. Sanksi kurungan harus merujuk pada hukum pidana kodifikasi tidak boleh melebihi 1 (satu) tahun, karena sanksi pidana dalam Peraturan Daerah umumnya bukanlah kejahatan 
tetapi hanya pelanggaran kecuali sanksi pidana pada Peraturan Daerah di Nangro Aceh Darusalam (NAD).

Kebijakan Pemerintahan Daerah dalam merumuskan Peraturan Daerah pidana perlu dipertimbangkan untuk mengefektifkan pelaksanaan sanksi pidana denda di masa akan datang yang berguna untuk mengurangi beban sistem peradilan pidana dan secara tidak langsung dapat menambah Pendapatan Asli Daerah (PAD).

Mengenai penetapan jumlah pidana denda, perlu kiranya dipikirkan suatu perumusan kebijakan Pemerintahan Daerah yang lebih longgar, mengingat pidana denda, berbeda dengan jenis pidana pokok lainnya, merupakan jenis pidana yang bernilai uang dan mempunyai nilai ekonomis. Pertimbangan yang utama tentang pidana denda mudah berubah nilainya karena pengaruh perkembangan moneter maupun perkembangan ekonomi suatu masyarakat, baik secara nasional maupun internasional. Setiap kebijakan Pemerintahan Daerah yang menaikkan jumlah pidana denda, akan tetapi mempunyai nilai relatif yang ada pada suatu waktu akan tetap dirasakan sebagai sanksi pidana yang ringan.

Menurut sistem KUHP, kurungan pengganti merupakan satu kesatuan sistem dengan pidana denda karena perhitungan didasarkan pada jumlah denda yang dijatuhkan. Kebijakan Pemerintahan Daerah mengenai jumlah pidana denda mudah berubah, maka hal ini harus pula diikuti dengan perubahan kebijakan Pemerintahan Daerah dalam perhitungan lamanya kurungan pengganti denda.

Penegakan hukum perbuatan pidana sebagai pelaksanaan Peraturan Peraturan daerah di daerah akan menjadi sangat penting, dalam era otonomi daerah, untuk membantu Pemerintah Daerah mempunyai keleluasaan dalam mengurus dan mengatur tertib hukum diwilayah pemerintahan di daerah.

Upaya mencegah duplikasi pengaturan itu ada kemungkinan pemerintah daerah akan menempuh kebijakan melakukan pembagian kewenangan antara PPNS dengan Satuan Polisi Pamongpraja. Apabila pemerintah daerah mengambil kebijakan seperti ini maka diperlukan kajian keberlakuan hukum untuk mengetahui bagaimana pembagian kewenangan itu dilaksanakan, agar tidak terjadi tumpang tindih peraturan hukum di daerah. Dalam Hukum Acara Pidana berlaku asas umum, bahwa hanya pejabat yang diberi wewenang khusus oleh undangundang saja yang berhak melaksanakan pemeriksaan perkara pidana dalam proses penegakan hukum. 
Suatu model kebijakan peradilan dan peradilan penal (Penal Policy) perlu dikembangkan untuk penegakan hukum peraturan daerah sehubungan dengan ketentuan sebagaimana diatur di dalam Pasal 6 KUHP.

Ketentuan acara pemeriksaan di persidangan, mengenai tindak pidana pelanggaran dalam Peraturan Daerah yang ancaman hukumannya di bawah 1 (satu) tahun, maka dapat dilakukan acara pemeriksaan singkat dalam proses beracara di pengadilan.

Konsep harmonisasi hukum antara bidang hukum pusat dan hukum lokal dalam hukum acara penyelesaian perkara pidana berdasarkan hukum Peraturan Daerah agar supaya tercipta didaerah guna memperlancar sistim desentralisasi daerah otonom dan demokratisasi peradilan pidana yang diselenggarakan oleh Pemerintah Daerah di kabupaten/ kota seluruh Republik Indonesia.

\section{Penutup}

Berpijak dari uraian di atas, dapat disimpulkan bahwa konsep dasar Pemerintahan Daerah dalam memformulasikan kebijakan kriminalisasi lebih menitik beratkan untuk menambah Pendapatan Asli Daerah (PAD) dan belum memperhatikan alasan kriminalisasi sesuai dengan teori kriminalisasi, sehingga persyaratan untuk melakukan kriminalisasi tidak sepenuhnya dilakukan. Alasan Pemerintah Daerah merumuskan pidana dalam Peraturan Daerah atau bermuatan pidana tidak ada keseragaman tergantung dari peraturan perundangan-undangan yang dijadikan dasar untuk pembuatan Peraturan Daerah, demikian juga dalam hal penentuan sanksi dalam Peraturan Daerah.

Belum terdapat sinkronisasi antara hukum pidana lokal dengan dengan hukum pidana kodifikasi, hal ini mengingat banyaknya aturan hukum yang dapat dirujuk sebagai dasar untuk pembuatan Peraturan Daerah, dan di antara masing-masing peraturan hukum tersebut terdapat rumusan sanksi yang berbeda-beda, juga dimungkinkan adanya perbedaan penafsiran dari pembentuk Peraturan Daerah. Teori pemidanaan dan tujuan pemidanaan dalam konteks penetapan sanksi pidana pada tahap kebijakan legislasi belum dipahami secara utuh sehingga jenis dan bentuk-bentuk sanksi di dalam Peraturan Daerah bukan saja menimbulkan ketidak konsistenan Peraturan Daerah yang satu dengan yang lain, tetapi juga penetapan sanksi dirasakan kurang objektif dan rasional. Ketidaksinkronan Peraturan Daerah dapat 
dilihat masih terdapatnya Peraturan Daerah yang dibatalkan oleh Menteri Dalam Negeri maupun Judicial Review oleh Makhamah Agung (MA).

Strategi yang perlu dikembangkan untuk mewujudkan sinkronisasi antara hukum pidana lokal dengan hukum pidana kodifikasi, meliputi: (1) Aspek materi hukum Peraturan Daerah Pidana harus ditumbuhkan acuhan dalil di samping sinkronisasi dengan hukum yang berada diatasnya dengan menggunakan prinsip "lex superiori derogat legi inferiori", juga harus diperhatikan aspek kesetaraan dengan menggunakan prinsip "lex specialis derogat legi generali"; serta memperhatikan jenis perbuatan masuk pelanggaran atau kejahatan. (2)Aspek Pidana dalam Peraturan Daerah di Jawa Tengah harus dapat dikualifikasikan sebagai: Sanksi Kurungan, Sanksi Denda dan Sanksi Administratif. (3) Dalam rangka menegakkan Peraturan Daerah, Pemerintah Daerah dapat membentuk badan-badan yang ditugasi untuk menegakkan Peraturan Daerah tersebut dengan mengacu kepada peraturan Hukum Acara Pidana yang ada, sehingga dapat dihindari kerancuan penanganan terhadap pelanggaran Peraturan Daerah.

\section{Daftar Pustaka}

Bagir Manan, Hukum Positif Indonesia: Satu Kajian Teoritik, FH UII Press, Yogyakarta, 2004

, Menyongsong Fajar Otomoni Daerah, PSH FH UII, Yogyakarta, 2002

Barda Nawawi Arief, Bunga Rampai Kebijakan Hukum Pidana, Citra Aditya Bakti, Bandung, 2002

D. Schaffmeister, et.al., Hukum Pidana, Liberty, Yogyakarta, 1995

Muladi, Kapita Selekta Hukum Pidana, Badan Penerbit Universitas Diponegoro, Semarang, 1995

Prayudi Atmosudirdjo, Hukum Administrasi Negara, Ghalia Indonesia, Jakarta, 1981

Roeslan Saleh, Segi Lain Hukum Pidana, Ghalia Indonesia, Jakarta, 1984

Undang-Undang Nomor 12 Tahun 1985 tentang Pajak Bumi dan Bangunan

Undang-Undang Nomor 23 Tahun 1992 tentang Kesehatan

Undang-Undang Nomor 23 Tahun 1997 tentang Pengelolaan Lingkungan Hidup

Undang-undang Nomor 22 Tahun 1999 tentang Pemerintahan Daerah

Undang-undang Nomor 32 Tahun 2004 tentang Pemerintahan Daerah 